\title{
Pseudoclavibacter chungangensis sp. nov., isolated from activated sludge
}

Correspondence
Wonyong Kim
kimwy@cau.ac.kr

\author{
Sung-Lim Cho, ${ }^{1}$ Min Young Jung, ${ }^{1,2}$ Mi-Hak Park, ${ }^{1}$ Young-Hyo Chang, ${ }^{2}$ \\ Jung-Hoon Yoon, ${ }^{2}$ Soon Chul Myung ${ }^{3}$ and Wonyong $\mathrm{Kim}^{1}$ \\ ${ }^{1}$ Department of Microbiology, Chung-Ang University College of Medicine, 221 Heukseok-dong, \\ Dongjak-gu, Seoul 156-756, Republic of Korea \\ ${ }^{2}$ Korea Research Institute of Bioscience and Biotechnology (KRIBB), PO Box 115, Yuseong, \\ Daejeon, Republic of Korea \\ ${ }^{3}$ Department of Urology, Chung-Ang University College of Medicine, 221 Heukseok-dong, \\ Dongjak-gu, Seoul 156-756, Republic of Korea
}

The family Microbacteriaceae embraces a large group of actinomycetes with cell-wall peptidoglycan of the B type (Schleifer \& Kandler, 1972) and unsaturated major menaquinones (Collins \& Jones, 1981). Initially, the family Microbacteriaceae was proposed to accommodate the genera Agromyces, Aureobacterium, Clavibacter, Curtobacterium and Microbacterium (Park et al., 1993). At the time of writing, Microbacteriaceae comprises 31 recognized genera, which are distinguishable at the phenotypic level by a number of chemotaxonomic characteristics, including peptidoglycan diamino acids and respiratory menaquinone composition (Collins \& Bradbury, 1992; Evtushenko \& Takeuchi, 2003; Sheridan et al., 2003). The genus Pseudoclavibacter was created to accommodate 'Brevibacterium helvolum' (Zimmermann, 1890; Lochhead, 1955; Manaia et al., 2004), an organism isolated from butter; the name is an earlier homotypic synonym of 'Zimmermannella helvola' (Lin et al., 2004). The genus name 'Zimmermannella' is illegitimate based on nomenclature rules. Other related organisms, namely 'Zimmermannella alba', ' $Z$. bifida', ' $Z$. faecalis' and Pseudoclavibacter soli, have been isolated from

Abbreviations: GYEA, glucose-yeast extract agar; GYEB, glucose-yeast extract broth.

The GenBank/EMBL/DDBJ accession number for the $16 \mathrm{~S}$ rRNA gene sequence of strain CAU $59^{\top}$ is FJ514934. human and animal specimens and soil (Lin et al., 2004; Kim \& Jung, 2009).

During the course of routine screening of bacteria for industrial purposes, a Pseudoclavibacter-like strain (designated CAU $59^{\mathrm{T}}$ ) was isolated from activated sludge at the wastewater treatment plant in Cheonan, Republic of Korea. The procedure for isolation of strain CAU $59^{\mathrm{T}}$ followed that of Gordon \& Mihm (1962) using glucose-yeast extract agar (GYEA; 10 g yeast extract $1^{-1}, 10$ g glucose $1^{-1}, 15 \mathrm{~g}$ agar $1^{-1}$ ) supplemented with $50 \mathrm{mg}$ cycloheximide $1^{-1}$ and $20 \mathrm{mg}$ nalidixic acid $1^{-1}$. An activated sludge sample was diluted with sterilized distilled water and appropriate dilutions were spread on GYEA medium and incubated aerobically for 3 days at $30{ }^{\circ} \mathrm{C}$.

The Gram-staining reaction and production of spores were determined by microscopic examination, following described procedures (Doetsch, 1981; Smibert \& Krieg, 1981). Catalase activity was determined by bubble production in a $3 \%(\mathrm{v} / \mathrm{v})$ hydrogen peroxide solution. Oxidase activity was tested by means of the oxidation of $1 \%$ tetramethyl $p$-phenylenediamine (Merck). Hydrolysis of casein, starch and urea was determined on GYEA according to described methods (Cowan \& Steel, 1965; Lányí, 1987; Smibert \& Krieg, 1994). Other enzymic activities were tested using the API ZYM and API 20E 
systems (bioMérieux), following the manufacturer's instructions. The fermentation of carbohydrates was characterized using the API $50 \mathrm{CH}$ system and defined medium B (Manaia et al., 2003). Growth with $0-15 \% \mathrm{NaCl}$ was investigated on glucose-yeast extract broth (GYEB) at $30{ }^{\circ} \mathrm{C}$. Growth at $4-50{ }^{\circ} \mathrm{C}$ was determined on GYEA. Growth at pH 3.0, 4.5 and 6.0 was determined in GYEB buffered with $12 \mathrm{mM}$ MES (Sigma) and at $\mathrm{pH}$ 8.0, 9.0, 10.0 and 11.0 in GYEB buffered with $15 \mathrm{mM}$ CAPS (Sigma).

Cellular fatty acid methyl esters were extracted after incubation for 3 days on tryptic soy agar (Difco) by acid methanolysis (Minnikin et al., 1980) and analysed using a gas chromatograph (model 56890N; Agilent) equipped with a cross-linked $5 \%$ phenyl methyl silicon-fused silica capillary column (HP 19091B-102; Hewlett Packard). Menaquinones were analysed as described by Komagata \& Suzuki (1987) using reversed-phase HPLC. For strain CAU $59^{\mathrm{T}}$, preparation of cell walls and analysis of peptidoglycan structures were carried out using the methods described by Schleifer (1985), except that TLC was performed on cellulose sheets instead of paper. An analysis of the cell-wall diamino acid was performed as described elsewhere (Groth et al., 1996; MacKenzie, 1987; Schleifer \& Kandler, 1972).

Genomic DNA of strain CAU $59^{\mathrm{T}}$ was isolated and purified by the method described by Marmur (1961). The G+C content of the genomic DNA was determined using SYBR Green I and a real-time thermocycler (model 7300; Applied Biosystems) and the fluorimetric method (Gonzalez \& Saiz-Jimenez, 2002). The extent of genomic DNA-DNA relatedness between the isolate and P. helvolus DSM $20419^{\mathrm{T}}$ was estimated using the fluorometric microplate method (Ezaki et al., 1989), as modified by Goris et al. (1998). PCR amplification of the 16S rRNA gene sequence of strain CAU $59^{\mathrm{T}}$ was carried out following established procedures (Nam et al., 2004). The PCR products were sequenced directly using a BigDye Terminator Cycle Sequencing kit and ABI 3730 automatic DNA sequencer (Applied Biosystems). The sequence obtained from strain CAU $59^{\mathrm{T}}$ was compared with corresponding sequences of other bacterial strains in the GenBank database. Multiple alignments with $16 \mathrm{~S}$ rRNA gene sequences from a broad selection of related species were carried out using CLUSTAL X (Thompson et al., 1997). Sequence similarity levels were calculated using PHYDIT and the EzTaxon server (Chun et al., 2007). A phylogenetic tree was constructed using neighbour-joining (Saitou \& Nei, 1987), least-squares (Fitch \& Margoliash, 1967) and maximum-likelihood (Felsenstein, 1981) algorithms from the PHYLIP suite of programs (Felsenstein, 1989). Evolutionary distances for the neighbour-joining analysis were based on the correction of Jukes \& Cantor (1969). The topology of the final tree was evaluated by the bootstrap method (Felsenstein, 1985) with 1000 replicates of the neighbour-joining dataset with the SEQBOOT and CONSENSE programs from the PHYLIP package.
Colonies of strain CAU $59^{\mathrm{T}}$ were strictly aerobic, opaque, yellow and circular, with a diameter of $1-3 \mathrm{~mm}$ after 3 days of cultivation at $30{ }^{\circ} \mathrm{C}$ on GYEA medium. Cells were short rods, approximately $0.1-0.2 \mu \mathrm{m}$ in width and $1.3-$ $1.7 \mu \mathrm{m}$ in length. Growth was observed at $4-50{ }^{\circ} \mathrm{C}$ (optimum $30{ }^{\circ} \mathrm{C}$ ) and at $\mathrm{pH} 3.0-11.0$ (optimum $\mathrm{pH}$ 7.0) on GYEA. Strain CAU $59^{\mathrm{T}}$ grew with $0-15 \%(\mathrm{w} / \mathrm{v}) \mathrm{NaCl}$ (optimum $5 \% \mathrm{NaCl}$ ). Cells of strain $\mathrm{CAU} 59^{\mathrm{T}}$ were catalase-positive and oxidase-negative.

Table 1. Differential phenotypic properties between strain CAU $59^{\top}$ and the type strains of closely related taxa of family Microbacteriaceae

Strains: 1, Pseudoclavibacter chungangensis sp. nov. CAU 59 ${ }^{\mathrm{T}} ; 2, P$. helvolus DSM $20419^{\mathrm{T}}$; 3, P. soli $\mathrm{KP}^{\mathrm{T}} 2^{\mathrm{T}}$; 4, 'Zimmermannella alba' NBRC 15616; 5, 'Z. bifida' IAM 14848; 6, 'Z. faecalis' NBRC 15706; 7, Gulosibacter molinativorax $\mathrm{ON}^{\mathrm{T}}$; 8, Curtobacterium pusillum DSM $20527^{\mathrm{T}}$. Data were obtained in this study. + , Positive; - , negative.

\begin{tabular}{|c|c|c|c|c|c|c|c|c|}
\hline Characteristic & 1 & 2 & 3 & 4 & 5 & 6 & 7 & 8 \\
\hline \multicolumn{9}{|l|}{ Enzyme activity } \\
\hline Alkaline phosphatase & + & - & - & + & + & - & - & - \\
\hline Cystine arylamidase & - & - & - & - & + & + & - & - \\
\hline Esterase (C4) & + & - & - & - & - & - & - & - \\
\hline Esterase lipase (C8) & + & - & - & - & - & + & - & - \\
\hline Valine arylamidase & + & - & + & - & - & - & - & + \\
\hline$\alpha$-Glucosidase & + & - & - & - & - & - & - & + \\
\hline$\beta$-Glucosidase & + & - & - & - & - & - & - & + \\
\hline$\alpha$-Mannosidase & - & - & - & - & - & - & - & + \\
\hline \multicolumn{9}{|l|}{ Assimilation of: } \\
\hline Glycerol & + & + & + & + & + & - & - & + \\
\hline D-Arabinose & - & + & - & + & + & - & - & + \\
\hline L-Arabinose & - & + & + & - & + & - & - & + \\
\hline D-Arabitol & - & + & - & - & + & - & - & + \\
\hline L-Arabitol & - & + & - & + & + & - & - & - \\
\hline Arbutin & - & + & - & - & + & - & - & + \\
\hline L-Arginine & - & - & - & + & - & - & - & + \\
\hline Aesculin & - & + & + & - & - & - & - & + \\
\hline D-Fructose & + & + & + & - & - & + & - & + \\
\hline D-Fucose & - & + & - & - & + & - & - & - \\
\hline L-Fucose & - & - & - & - & + & - & - & + \\
\hline D-Glucose & - & + & + & + & - & + & - & + \\
\hline Inositol & - & + & - & - & - & + & - & + \\
\hline Inulin & - & - & - & - & + & - & - & - \\
\hline D-Lyxose & - & + & - & - & - & - & - & - \\
\hline Melibiose & - & + & - & - & - & - & + & + \\
\hline D-Mannitol & + & + & + & + & + & + & - & + \\
\hline Raffinose & + & + & - & + & - & - & - & + \\
\hline D-Ribose & - & + & - & + & + & + & - & + \\
\hline Salicin & - & + & + & + & - & - & - & + \\
\hline Sucrose & + & + & - & - & - & - & + & - \\
\hline Starch & - & - & - & + & + & - & - & - \\
\hline D-Tagatose & - & + & + & + & - & - & - & + \\
\hline Trehalose & - & + & - & + & + & - & - & + \\
\hline Turanose & - & + & - & - & + & - & - & + \\
\hline Xylitol & - & + & - & - & - & - & - & + \\
\hline L-Xylose & - & + & - & + & - & - & - & - \\
\hline
\end{tabular}


Table 2. Chemotaxonomic characteristics of strain CAU $59^{\top}$ and other closely related species

Strains: 1, Pseudoclavibacter chungangensis sp. nov. CAU 59 ${ }^{\mathrm{T}}$; 2, P. helvolus DSM 20419 ${ }^{\mathrm{T}}$; 3, P. soli KP02 ${ }^{\mathrm{T}}$; 4, 'Zimmermannella alba' NBRC 15616; 5, 'Z. bifida' IAM 14848; 6, 'Z. faecalis' NBRC 15706; 7, Gulosibacter molinativorax ON4 ${ }^{\mathrm{T}}$; 8, Curtobacterium pusillum DSM $20527^{\mathrm{T}}$. Data were obtained in this study unless otherwise indicated. +, Positive; tr, trace $(<1.0 \%)$; , not detected. DAB, 2,4-diaminobutyric acid; ECL, equivalent chain-length; Hsr, homoserine.

\begin{tabular}{|c|c|c|c|c|c|c|c|c|}
\hline Fatty acid (\%) & 1 & 2 & 3 & 4 & 5 & 6 & 7 & 8 \\
\hline \multicolumn{9}{|l|}{ Saturated } \\
\hline $\mathrm{C}_{14: 0}$ & 1.2 & $\operatorname{tr}$ & $\operatorname{tr}$ & - & $\operatorname{tr}$ & $\operatorname{tr}$ & - & $\operatorname{tr}$ \\
\hline $\mathrm{C}_{16: 0}$ & 3.6 & 4.7 & 3.6 & 1.4 & $\operatorname{tr}$ & 5.4 & 1.9 & 1 \\
\hline \multicolumn{9}{|l|}{ Unsaturated } \\
\hline $\mathrm{C}_{18: 1} \omega 7 c$ & - & - & - & - & - & - & - & 32.7 \\
\hline $\mathrm{C}_{20: 1} \omega 9 c$ & - & - & 5.7 & - & - & - & 7.9 & - \\
\hline \multicolumn{9}{|l|}{ Branched-chain } \\
\hline anteiso- $\mathrm{C}_{13: 0}$ & - & 1.6 & $\operatorname{tr}$ & $\operatorname{tr}$ & 1.6 & $\operatorname{tr}$ & - & - \\
\hline anteiso- $\mathrm{C}_{15: 0}$ & 35.0 & 59.4 & 48 & 36.2 & 68.4 & 51.2 & 53.9 & 29.3 \\
\hline anteiso- $\mathrm{C}_{17: 0}$ & 17.5 & 25.2 & 21.7 & 55.6 & 16.2 & 13.8 & 17.4 & 23.4 \\
\hline cyclo- $\mathrm{C}_{19: 0} \omega 8 \mathrm{c}$ & 1.3 & - & - & - & - & - & - & - \\
\hline iso- $\mathrm{C}_{14: 0}$ & 2.1 & $\operatorname{tr}$ & $\operatorname{tr}$ & - & 1.4 & 2 & $\operatorname{tr}$ & $\operatorname{tr}$ \\
\hline iso- $\mathrm{C}_{15: 0}$ & - & - & 3.9 & $\operatorname{tr}$ & 3.5 & 2.7 & 1.6 & 4.4 \\
\hline iso- $\mathrm{C}_{16: 0}$ & 27.3 & 6.8 & 13.4 & $\operatorname{tr}$ & 5.7 & - & 16.7 & 6.3 \\
\hline iso- $\mathrm{C}_{17: 0}$ & - & - & 1.6 & 1.6 & $\operatorname{tr}$ & $\operatorname{tr}$ & - & 1.9 \\
\hline Summed feature $1^{\star}$ & 1.1 & - & - & $\operatorname{tr}$ & - & - & - & - \\
\hline Unknown fatty acid ECL & 5.5 & - & - & - & - & - & - & - \\
\hline Cell-wall amino acid(s) & DL-DAB & $\mathrm{DL}-\mathrm{DAB} \dagger$ & DL-DAB $\ddagger$ & L-DABS & L-DABS & Hsr, L-DAB§ & $\mathrm{D}-\mathrm{Orn} \dagger$ & D-Ornll \\
\hline Cell-wall sugar(s) & Fuc & Xyl, Gal & Xyl & Rha & Rha & Rha, Fuc & Fuc & Rha, Glu, Gal \\
\hline Predominant menaquinone & MK-9 & MK-9† & MK-9, MK-8 & MK-10\$ & MK-8, MK-9\$ & MK-9\$ & MK-9† & MK-9|| \\
\hline
\end{tabular}

*Summed features represent two or three fatty acids that cannot be separated by the Microbial Identification System. Summed feature 1 consisted of iso- $\mathrm{C}_{15: 0} \mathrm{H}$ and/or $\mathrm{C}_{13: 0}$ 3-OH.

$\dagger$ Data from Manaia et al. (2004).

$\ddagger$ Data from Kim \& Jung (2009).

§Data from Lin et al. (2004).

IIData from Behrendt et al. (2002) and Manaia et al. (2004).

The API systems provided adequate phenotypic data to describe the new isolate. A detailed description of the phenotypic characteristics is given in Table 1 and the species description. Using API $50 \mathrm{CHB}$, acids were produced from D-fructose, glycerol, 5-ketogluconate, Dmannitol, raffinose and D-xylose. API ZYM detected acid phosphatase, alkaline phosphatase, esterase (C4), esterase lipase (C8), $\alpha$ - and $\beta$-glucosidase, leucine arylamidase, valine arylamidase and naphthol-AS-BI-phosphohydrolase. API 20E demonstrated the utilization of L-tryptophan and sodium pyruvate.

The diamino acid in the peptidoglycan of strain CAU $59^{\mathrm{T}}$ was 2,4-diaminobutyric acid and alanine, glycine and glutamic acid were also found: the molar ratios were $2.0: 0.8: 1.2: 1.0$. The cell-wall sugars contained fucose. The predominant isoprenoid quinone was the unsaturated menaquinone MK-9. The cellular fatty acid profile contained $\mathrm{C}_{14: 0}(1.2 \%), \mathrm{C}_{16: 0}(3.6 \%)$, anteiso- $\mathrm{C}_{15: 0}$ $(35.0 \%)$, anteiso- $\mathrm{C}_{17: 0}(17.5 \%)$, cyclo- $\mathrm{C}_{19: 0} \omega 8_{c}(1.3 \%)$, iso- $\mathrm{C}_{14: 0}(2.1 \%)$, iso- $\mathrm{C}_{16: 0}(27.3 \%)$, summed feature 1 $(1.1 \%)$ and an unknown fatty acid (5.5\%; Table 2).
The $\mathrm{G}+\mathrm{C}$ content of the genomic DNA of strain CAU $59^{\mathrm{T}}$ was approximately $66.2 \mathrm{~mol} \%$. A phylogenetic tree based on 16S rRNA gene sequences (1424 bp) from strain CAU $59^{\mathrm{T}}$ and closely related type strains in the family Microbacteriaceae was constructed using combinations of different algorithms (Fig. 1). It is evident that strain CAU $59^{\mathrm{T}}$ falls within the cluster comprising Pseudoclavibacter species, forming a clade with $P$. helvolus DSM $20419^{\mathrm{T}}$, and is clearly separated from the members of the genera Clavibacter, Curtobacterium, Mycetocola and Frigoribacterium. Pairwise similarity values between strain CAU $59^{\mathrm{T}}$ and closely related strains were $96.7 \%$ ('Z. alba' IFO 15616), $96.4 \%$ (P. helvolus DSM $20419^{\mathrm{T}}$ ), $95.5 \%$ (' $Z$. faecalis' IFO 15706), $95.2 \%$ (' $Z$. bifida' IAM 14848), $95.2 \%$ (Gulosibacter molinativorax $\mathrm{ON}^{\mathrm{T}}$ ) and $94.5 \%\left(P\right.$. soli $\left.\mathrm{KP} 02^{\mathrm{T}}\right)$. The high sequence divergence values with recognized members of the genus Pseudoclavibacter $(>3.6 \%)$ clearly indicate that strain CAU $59^{\mathrm{T}}$ represents a novel species within the genus (Stackebrandt \& Goebel, 1994). The mean DNA-DNA relatedness value between strain CAU $59^{\mathrm{T}}$ and P. helvolus DSM $20419^{\mathrm{T}}$ was $20.9 \%$. This value is well below the $70 \%$ cut-off point recommended by Wayne et al. (1987) for the delineation of a 


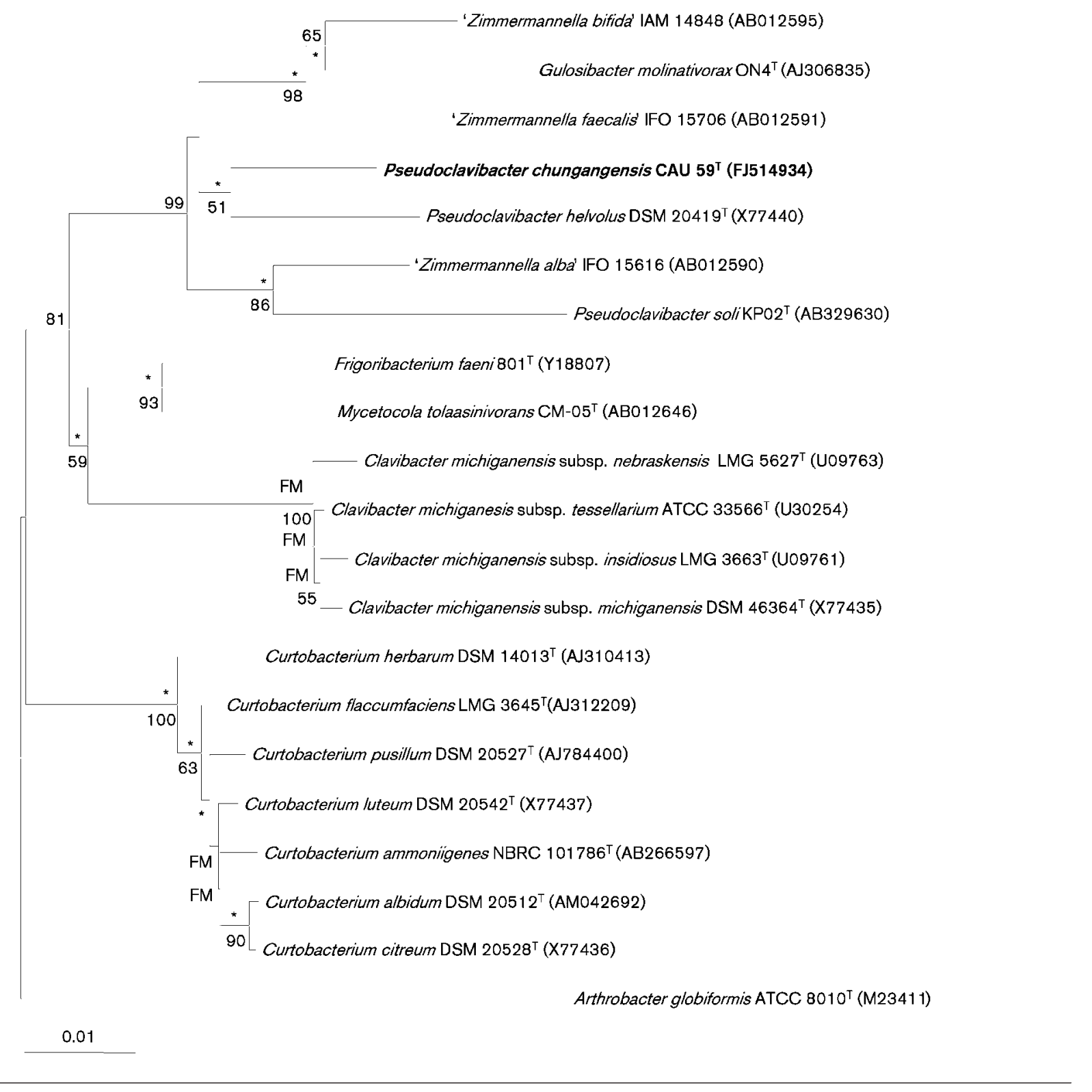

Fig. 1. Neighbour-joining phylogenetic tree based on 16S rRNA gene sequences showing the relationships between strain CAU $59^{\top}$ and type strains of closely related taxa of family Microbacteriaceae. Bootstrap values (>50\%) based on 1000 replications are shown at branch nodes. Asterisks indicate that the corresponding nodes were recovered in trees generated with the concurrent use of the least-squares and maximum-likelihood algorithms. F or $\mathrm{M}$ indicates that the corresponding nodes were recovered in trees generated with the least-squares algorithm or maximum-likelihood algorithm, respectively. Bar, 0.01 substitutions per nucleotide position.

genomic species, supporting the proposal that CAU $59^{\mathrm{T}}$ represents a novel species.

These phenotypic and chemotaxonomic data, together with the $16 \mathrm{~S}$ rRNA gene sequence data and the DNA-DNA relatedness study, provide sufficient evidence to support the proposal that strain CAU $59^{\mathrm{T}}$ represents a hithertounrecognized species within the genus Pseudoclavibacter. The name Pseudoclavibacter chungangensis sp. nov. is proposed.

\section{Description of Pseudoclavibacter chungangensis} sp. nov.

Pseudoclavibacter chungangensis (chung.an.gen'sis. N.L. masc. adj. chungangensis named after Chung-Ang University, where the taxonomic studies on the type strain were performed).

Cells are strictly aerobic, Gram-positive, non-spore-forming rods, $0.1-0.2 \mu \mathrm{m}$ in width and $1.3-1.7 \mu \mathrm{m}$ in length. Colonies are yellow, opaque and circular on GYEA 
medium. Growth occurs at $4-50{ }^{\circ} \mathrm{C}$ (optimum $30{ }^{\circ} \mathrm{C}$ ), at $\mathrm{pH} 3.0-11.0$ (optimum $\mathrm{pH} 7.0$ ) and with $0-15 \%(\mathrm{w} / \mathrm{v})$ $\mathrm{NaCl}$ (optimum $5 \%$ ). Catalase-positive and oxidasenegative. Acid is produced from D-fructose, glycerol, 5ketogluconate, D-mannitol, raffinose and D-xylose. Casein, starch and urea are not hydrolysed. Enzyme activities were demonstrated for acid phosphatase, alkaline phosphatase, esterase (C4), esterase lipase (C8), $\alpha$ - and $\beta$-glucosidase, leucine arylamidase, valine arylamidase and naphthol-ASBI-phosphohydrolase. L-tryptophan and sodium pyruvate are utilized. The diamino acid in the peptidoglycan is 2,4diaminobutyric acid. The major isoprenoid quinone is MK-9. Whole-cell hydrolysates contain mainly fucose. The predominant cellular fatty acids $(>10 \%)$ are anteiso- $\mathrm{C}_{15: 0}$, anteiso- $\mathrm{C}_{17: 0}$ and iso- $\mathrm{C}_{16: 0}$. The DNA G $+\mathrm{C}$ content of the type strain is $66.2 \mathrm{~mol} \%$.

The type strain $\left(\right.$ CAU $59^{\mathrm{T}}=$ KCTC $22691^{\mathrm{T}}=$ CCUG $\left.58142^{\mathrm{T}}\right)$ was isolated from activated sludge taken from a wastewater treatment plant in Cheonan, Republic of Korea.

\section{Acknowledgements}

This study was supported by a grant of the Korea Healthcare technology R\&D Project, Ministry for Health, Welfare \& Family Affairs, Republic of Korea (A085138).

\section{References}

Behrendt, U., Ulrich, A., Schumann, P., Naumann, D. \& Suzuki, K. (2002). Diversity of grass-associated Microbacteriaceae isolated from the phyllosphere and litter layer after mulching the sward; polyphasic characterization of Subtercola pratensis sp. nov., Curtobacterium herbarum sp. nov. and Plantibacter flavus gen. nov., sp. nov. Int J Syst Evol Microbiol 52, 1441-1454.

Chun, J., Lee, J. H., Jung, Y., Kim, M., Kim, S., Kim, B. K. \& Lim, Y. W. (2007). EzTaxon: a web-based tool for the identification of prokaryotes based on $16 \mathrm{~S}$ ribosomal RNA gene sequences. Int J Syst Evol Microbiol 57, 2259-2261.

Collins, M. D. \& Bradbury, J. F. (1992). The genera Agromyces, Aureobacterium, Clavibacter, Curtobacterium, and Microbacterium. In The Prokaryotes, 2nd edn, pp. 1355-1368. Edited by A. Balows, H. G. Trüper, M. Dworkin, W. Harder \& K. H. Schleifer. New York: Springer.

Collins, M. D. \& Jones, D. (1981). The distribution of isoprenoid quinone structural types in bacteria and their taxonomic implications. Microbiol Rev 45, 316-354.

Cowan, S. T. \& Steel, K. J. (1965). Manual for the Identification of Medical Bacteria. London: Cambridge University Press.

Doetsch, R. N. (1981). Determinative methods of light microscopy. In Manual of Methods for General Bacteriology, pp. 21-33. Edited by P. Gerhardt, R. G. E. Murray, R. N. Costilow, E. W. Nester, W. A. Wood, N. R. Krieg \& G. H. Phillips. Washington, DC: American Society for Microbiology.

Evtushenko, L. I. \& Takeuchi, M. (2003). The family Microbacteriaceae. In The Prokaryotes: a Handbook on the Biology of Bacteria, 3rd edn, vol. 3, pp. 1020-1098. Edited by M. Dworkin, S. Falkow, E. Rosenberg, K. H. Schleifer \& E. Stackebrandt. New York: Springer.

Ezaki, T., Hashimoto, Y. \& Yabuuchi, E. (1989). Fluorometric deoxyribonucleic acid-deoxyribonucleic acid hybridization in microdilution wells as an alternative to membrane filter hybridization in which radioisotopes are used to determine genetic relatedness among bacterial strains. Int J Syst Bacteriol 39, 224-229.

Felsenstein, J. (1981). Evolutionary trees from DNA sequences: a maximum likelihood approach. J Mol Evol 17, 368-376.

Felsenstein, J. (1985). Confidence limits on phylogenies: an approach using the bootstrap. Evolution 39, 783-791.

Felsenstein, J. (1989). PHYLIP - phylogeny inference package (version 3.2). Cladistics 5, 164-166.

Fitch, W. M. \& Margoliash, E. (1967). Construction of phylogenetic trees. Science 155, 279-284.

Gonzalez, J. M. \& Saiz-Jimenez, C. (2002). A fluorimetric method for the estimation of $\mathrm{G}+\mathrm{C}$ mol\% content in microorganisms by thermal denaturation temperature. Environ Microbiol 4, 770773.

Gordon, R. E. \& Mihm, J. M. (1962). Identification of Nocardia caviae (Erikson) nov. comb. Ann N Y Acad Sci 98, 628-636.

Goris, J., Suzuki, K., De Vos, P., Nakase, T. \& Kersters, K. (1998). Evaluation of a microplate DNA-DNA hybridization method compared with the initial renaturation method. Can J Microbiol 44, 1148-1153.

Groth, I., Schumann, P., Weiss, N., Martin, K. \& Rainey, F. A. (1996). Agrococcus jenensis gen. nov., sp. nov., a new genus of actinomycetes with diaminobutyric acid in the cell wall. Int J Syst Bacteriol 46, 234239.

Jukes, T. H. \& Cantor, C. R. (1969). Evolution of protein molecules. In Mammalian Protein Metabolism, vol. 3, pp. 21-132. Edited by H. N. Munro. New York: Academic Press.

Kim, M. K. \& Jung, H.-Y. (2009). Pseudoclavibacter soli sp. nov., a $\beta$ glucosidase-producing bacterium. Int J Syst Evol Microbiol 59, 835838.

Komagata, K. \& Suzuki, K. (1987). Lipid and cell-wall analysis in bacterial systematics. Methods Microbiol 19, 161-207.

Lányí, B. (1987). Classical and rapid identification methods for medically important bacteria. Methods Microbiol 19, 1-67.

Lin, Y.-C., Uemori, K., de Briel, D. A., Arunpairojana, V. \& Yokota, A. (2004). Zimmermannella helvola gen. nov., sp. nov., Zimmermannella alba sp. nov., Zimmermannella bifida sp. nov., Zimmermannella faecalis sp. nov. and Leucobacter albus sp. nov., novel members of the family Microbacteriaceae. Int J Syst Evol Microbiol 54, 16691676.

Lochhead, A. G. (1995). Brevibacterium helvolum (Zimmermann) comb. nov. Int Bull Bact Nomen Taxon 5, 115.

MacKenzie, S. L. (1987). Gas chromatographic analysis of amino acids as the $N$-heptafluorobutyryl isobutyl esters. J Assoc Off Anal Chem 70, 151-160.

Manaia, C. M., Nunes, O. C. \& Nogales, B. (2003). Caenibacterium thermophilum gen. nov., sp. nov., isolated from a thermophilic aerobic digester of municipal sludge. Int J Syst Evol Microbiol 53, 1375-1382.

Manaia, C. M., Nogales, B., Weiss, N. \& Nunes, O. C. (2004). Gulosibacter molinativorax gen. nov., sp. nov., a molinate-degrading bacterium, and classification of 'Brevibacterium helvolum' DSM 20419 as Pseudoclavibacter helvolus gen. nov., sp. nov. Int J Syst Evol Microbiol 54, 783-789.

Marmur, J. (1961). A procedure for the isolation of deoxyribonucleic acid from microorganisms. J Mol Biol 3, 208-218.

Minnikin, D. E., Hutchinson, I. G., Caldicott, A. B. \& Goodfellow, M. (1980). Thin-layer chromatography of methanolysates of mycolic acid-containing bacteria. J Chromatogr A 188, 221-233. 
Nam, S. W., Kim, W., Chun, J. \& Goodfellow, M. (2004). Tsukamurella pseudospumae sp. nov., a novel actinomycete isolated from activated sludge foam. Int J Syst Evol Microbiol 54, 1209-1212.

Park, Y. H., Suzuki, K., Yim, D. G., Lee, K. C., Kim, E., Yoon, J., Kim, S., Kho, Y. H., Goodfellow, M. \& Komagata, K. (1993). Suprageneric classification of peptidoglycan group B actinomycetes by nucleotide sequencing of $5 \mathrm{~S}$ ribosomal RNA. Antonie van Leeuwenhoek 64, 307313.

Saitou, N. \& Nei, M. (1987). The neighbor-joining method: a new method for reconstructing phylogenetic trees. Mol Biol Evol 4, 406425.

Schleifer, K. H. (1985). Analysis of the chemical composition and primary structure of murein. Methods Microbiol 18, 123-156.

Schleifer, K. H. \& Kandler, O. (1972). Peptidoglycan types of bacterial cell walls and their taxonomic implications. Bacteriol Rev 36, 407-477.

Sheridan, P. P., Loveland-Curtze, J., Miteva, V. I. \& Brenchley, J. E. (2003). Rhodoglobus vestalii gen. nov., sp. nov., a novel psychrophilic organism isolated from an Antarctic Dry Valley lake. Int J Syst Evol Microbiol 53, 985-994.

Smibert, R. M. \& Krieg, N. R. (1981). General characterization. In Manual of Methods for General Microbiology, pp. 409-443. Edited by P. Gerhardt, R. G. E. Murray, R. N. Costilow, E. W. Nester, W. A.
Wood, N. R. Krieg \& G. B. Phillips. Washington, DC: American Society for Microbiology.

Smibert, R. M. \& Krieg, N. R. (1994). Phenotypic characterization. In Methods for General and Molecular Bacteriology, pp. 607-654. Edited by P. Gerhardt, R. G. E. Murray, W. A. Wood \& N. R. Krieg. Washington, DC: American Society for Microbiology.

Stackebrandt, E. \& Goebel, B. M. (1994). Taxonomic note: a place for DNA-DNA reassociation and 16S rRNA sequence analysis in the present species definition in bacteriology. Int J Syst Bacteriol 44, 846849.

Thompson, J. D., Gibson, T. J., Plewniak, F., Jeanmougin, F. \& Higgins, D. G. (1997). The CLUSTAL_X windows interface: flexible strategies for multiple sequence alignment aided by quality analysis tools. Nucleic Acids Res 25, 4876-4882.

Wayne, L. G., Brenner, D. J., Colwell, R. R., Grimont, P. A. D., Kandler, O., Krichevsky, M. I., Moore, L. H., Moore, W. E. C., Murray, R. G. E. \& other authors (1987). International Committee on Systematic Bacteriology. Report of the ad hoc committee on reconciliation of approaches to bacterial systematics. Int J Syst Bacteriol 37, 463-464.

Zimmermann, O. E. R. (1890). Die Bakterien unserer Trink- und Nutzwasser, inabesondere des Wassers der Chemnitzer Wasserleitung, pp. 53-154. Eleventh Report, Naturwiss Ges Chemnitz. 